\title{
Canine Herpesvirus Latent Infection in Experimentally Infected Rabbits
}

\section{G. F. Nájera Jantes, J. Barrón González, E. G. Valdivia Lara, J. I. Ángeles Solis, C. Cuenca Verde, G. Valdivia Anda*}

\author{
Laboratorio de Patogenicidad Microbiana, Unidad de Investigación Multidisciplinaria FESC-UNAM, Cuautitlán Izcalli, \\ Estado de México, México \\ Email: mvzgabnaj@gmail.com, josue.barron@gmail.com, guillermo897@hotmail.com,ccuencaverde@hotmail.com, \\ *valdivag@unam.mx
}

How to cite this paper: Jantes, G.F.N., González, J.B., Lara, E.G.V., Solis, J.I.A., Verde, C.C. and Anda, G.V. (2020) Canine Herpesvirus Latent Infection in Experimentally Infected Rabbits. Open Journal of Veterinary Medicine, 10, 92-102.

https://doi.org/10.4236/ojvm.2020.106008

Received: April 15, 2020

Accepted: June 27, 2020

Published: June 30, 2020

Copyright $\odot 2020$ by author(s) and Scientific Research Publishing Inc. This work is licensed under the Creative Commons Attribution International License (CC BY 4.0).

http://creativecommons.org/licenses/by/4.0/

(c) (i) Open Access

\begin{abstract}
An experimental inoculation of canine Herpesvirus (HVC), strain H17, was performed in rabbits previously and simultaneously treated with dexamethasone, the behavior of the leukocyte count was followed prior and during the experimental phase. Upon death or euthanasia of the animals, a necropsy and evaluation of various organs was performed by histopathology and by nested PCR against the Herpesvirus Polymerase gene. All animals inoculated with dexamethasone showed leukopenia $(\mathrm{p}<0.05)$, animals inoculated with HVC and treated with dexamethasone did not show significant histological lesions, but showed amplification of the Herpesvirus Polymerase gene in various organs despite not showing clinical signs of the illness. A dolphin Herpesvirus isolate was used as a positive control as rabbits developed fatal systemic disease and lesions typical of active (lytic) infection in various organs within 72 hours post-inoculation. The absence of clinical signs, significant histological lesions, and the presence of viral DNA in some organs suggested a state of latency due to canine Herpesvirus. Dexamethasone allowed HVC infection, but did not promote viral reactivation in rabbits contrary to that observed in canines experimentally induced to the lytic cycle by HVC.
\end{abstract}

\section{Keywords}

Rabbit and Canine Herpesvirus, Experimental Infection, Dexametasone and Latency

\section{Introduction}

Canine Herpesvirus (CHV-1) belongs to the herpesviridae family, a subgroup of alpha herpesviruses, which possess the ability to generate a latency state in the 
infected cells. Under circumstances of stress, pregnancy or treatment with immunosuppressive drugs, the latency state is reversed, and a viral reactivation occurs [1]. Latency is a feature shared among herpesviruses that allows them to persist indefinitely in the host after a primary or secondary infection [2]. During latency, viral DNA is found in a circular, non-integrated form, mainly in the nucleus of sensory nerve cells [3].

An effective viral reactivation has been accomplished in multiple experiments, through steroidal drugs administration in dogs and other animals that were previously infected with the virus [4].

Adult dogs have been intranasally, intravenously and vaginally infected with CHV-1; independently of the inoculation route, viral DNA has been detected in retropharyngeal lymph nodes and trigeminal ganglia by PCR [5]. When ocullary inoculated, CHV-1 has successfully established a latency state after bilateral conjunctivitis in dogs [6]. On the other hand, Burr, and Campbell, 1996 [7], established that the most commonly infected organs in dogs inoculated with CHV-1 are: Lumbosacral ganglia, tonsils, liver, and parotid salivary glands.

The rabbit has been widely used as an experimental model due to its good temperament, easy handling, care and reproduction. New Zealand breed has been mentioned as an ideal model for ocular lesions produced by hespesvirus simplex 1 (HSV-1) [8]. Rabbits have been used in the study of seroprevalence, neuropathogenicity and biological behaviour of Bovine Herpesvirus types 1 and 5 [9]. Furthermore, nervous signs in rabbits have been replicated by infection with Bovine herpesvirus type 5 [10]. Viral reactivation of Bovine herpesvirus type 5 has been effectively induced with dexamethasone in latently infected rabbits [11]. However, experimental infection with CHV-1 has not been accomplished in rabbits. Therefore, the aim of the present work was to establish and evaluate a CHV-1 infection in previously immunosuppressed rabbits.

\section{Methodology}

Thirty New Zealand rabbits weighing 1.9 to $2.1 \mathrm{Kg}, 3$ months old and males, were used in the experimental study. Animals were kept according to current Mexican guidelines [12] "Technical specifications for the production, care and use of laboratory animals") in an isolation unit (DIVeT ${ }^{\oplus}$ laboratory, State of Mexico, Mexico).

To assess the health status of the rabbits, a clinical examination and a complete blood count were performed one day before the start of the study and rutinarily until euthanasia or death.

The experimental design (Table 1) was carried out taking into account previous publications of the use of Herpesvirus in rabbits [9] [11] [13], and previous data of the experimental infection of rabbits using a herpesvirus isolated from free-living dolphins [14], which was highly virulent in the rabbit model (unpublished results).

Rabbits were divided into 7 groups (A to F). Individuals in groups A, B C and 
Table 1. Experimental design used.

\begin{tabular}{|c|c|c|c|c|}
\hline Group & $\begin{array}{l}\text { Number of animals } \\
\text { (identification) }\end{array}$ & $\begin{array}{l}\text { Dexametasone } \\
(4 \mathrm{mg} / \mathrm{im} / \text { day })\end{array}$ & $\begin{array}{l}\text { Inoculum } \\
\text { (day) }\end{array}$ & Death \\
\hline A & $8(\mathrm{~A} 1-\mathrm{A} 8)$ & Day 1 - 17 & $\mathrm{CHV}(8)$ & Euthanasia at day 18 \\
\hline B & $6(\mathrm{~B} 1-\mathrm{B} 6)$ & Day $1-17$ & NO & Euthanasia at day 18 \\
\hline $\mathrm{C}$ & $6(\mathrm{C} 1-\mathrm{C} 6)$ & Day $9-17$ & CHV (8) & Euthanasia at day 18 \\
\hline CII & 6 (CII1 - CII6) & NO & CHV (8) & Euthanasia at day 18 \\
\hline $\mathrm{D}$ & $4(\mathrm{D} 1-\mathrm{D} 4)$ & No & NO & Euthanasia at day 18 \\
\hline $\mathrm{E}$ & $3(\mathrm{E} 1-\mathrm{E} 3)$ & No & DHV (8) & Death at 3 days p.i. \\
\hline $\mathrm{F}$ & $3(\mathrm{~F} 1-\mathrm{F} 3)$ & Day 1 - 3 & DHV (D8) & Death at 3 days p.i. \\
\hline
\end{tabular}

$n=36$, CHV: canine Herpesvirus, DHV: dolphin Herpesvirus.

F were given daily intramuscular administration (im) of $4 \mathrm{mg}$ of dexamethasone sodium phosphate (Brulin ${ }^{\oplus}, 8 \mathrm{mg} / 2 \mathrm{ml}$ ) from day 1 to 17 (in groups $\mathrm{A}, \mathrm{B}$ ), and from day 9 to 17 (in group C). Likewise, the group F could only be administered dexamethasone for 3 days, due to their death. Group D was used as a negative control (not dexamethasone treatment). Dose of $4 \mathrm{mg} / \mathrm{rabbit} /$ day was used to reach a four-time higher dose, representing a slightly modification of what [9] Ledbetter C. E., and Sung G. K., 2009 employed in adult dogs.

Groups $\mathrm{E}$ and $\mathrm{F}$ were used as a positive controls for severe active herpesvirus lesions (lytic cycle), with (group F) or without (group E) dexamethasone treatment, by inoculating with a strain of dolphin Herpesvirus, previously isolated in Mexico [14], were intramuscullary inoculated on day 8 with $1 \mathrm{ml}\left(1 \times 10^{6}\right.$ viral particles) of Dolphin Herpesvirus filtrate obtained from an infected Madin Darby Bovine Kidney Cell Line (MDBK) (p172) for $72 \mathrm{~h}$.

On day 8, groups A, C and CII were intramuscullary inoculated with $1 \mathrm{ml}$ of CHV-1 (strain H17, previously isolated by our group) containing $1 \times 10^{6}$ viral particles. of Canine Herpesvirus filtrate obtained from an infected Madin-Darby Canine Kidney (MDCK) (pass 172) for $72 \mathrm{~h}$.

On day 1,8 and 18, blood was obtained from the 30 rabbits belonging to groups A, B, C, CII and D. Subsequently, euthanasia was done at day 18 , as indicated by the official Mexican guidelines [15], "Methods to euthanasia of domestic and wild animals".

A complete necropsy was performed, according to the "Manual of necropsy techniques for general pathology" [16]. Multiple organs were obtained and preserved in buffered formalin for histopathological study, or frozen at $-20^{\circ} \mathrm{C}$ for nested PCR, as previously described [17].

In the same way, the 6 rabbits in groups $\mathrm{E}$ and $\mathrm{F}$, who died at $72 \mathrm{~h}$ post virus inoculation, underwent a necropsy.

For nested PCR, a commercial DNA extraction kit was used (DNeasy Blood and Tissue Kit, Qiagen ${ }^{\mathrm{TM}}$ ) according to the manufacturer's protocol. DNA polymerase gene was amplified using the protocol described by [18], this technique identifies all the different herpesviruses from humans and animals. The protocol 
was based on nested PCR; for the first reaction, two forward and one reverse primer were used: DFA, 5'-TTY GAY AGY GCI YTI TAY CC-3' (forward); ILK, 5'-TCC TGG AGC AGC ACA ARI YSG CIM TIA A-3' (forward); KG1, 5'-GTC TTG CTCA CCA GIT CIA CIC CYT T3' (reverse). For the second reaction, one forward (TGV, 5'-TGT GTG TCG AAC TAY TTY ACI GGI GGI GT-3') and one reverse primer were utilized (IYG, 5'CAC CGT AGA GTC ICC RTA RTC IAT-3'). Briefly, for the first reaction, $400 \mathrm{ng}$ of DNA, $400 \mathrm{~nm}$ of each primer, $100 \mu \mathrm{M}$ of each dNTP, $10 \mathrm{mM} \mathrm{KCl,} 10 \mathrm{mM}\left(\mathrm{NH}_{4}\right)_{2} \mathrm{SO}_{4}, 20 \mathrm{mMTris}-\mathrm{HCl}, 2 \mathrm{mM}$ $\mathrm{MgSO}_{4}, 0.1 \%$ Triton X-100 at pH 8.8 and 1 unit of Taq polymerase (Bioline ${ }^{\mathrm{TM}}$, USA) were used. The mixture was placed in a Multigene thermocycler (International Labnet ${ }^{\mathrm{TM}}$ ) with an initial incubation at $94^{\circ} \mathrm{C}$ for $5 \mathrm{~min}, 35$ cycles at $94^{\circ} \mathrm{C}$ for $20 \mathrm{sec}, 46^{\circ} \mathrm{C}$ for $30 \mathrm{sec}$, and $72^{\circ} \mathrm{C} 30 \mathrm{sec}$, with a final step of 10 minutes at $72^{\circ} \mathrm{C}$. For the second nested PCR reaction, the same concentrations were used, with $5 \mu \mathrm{l}$ from the first reaction as template DNA. Finally, horizontal electrophoresis was performed in a $3 \%$ agarose gel, contain $0.5 \mu \mathrm{g} / \mathrm{ml}$ ethidium bromide, and was visualized on a UV light transilluminator. An expected product of 215 - $315 \mathrm{pb}$, was taken as positive [17].

Formalin-fixed tissues were embedded in paraffin, cut at $4 \mu \mathrm{m}$ and stained with hematoxylin and eosin as indicated in the Laboratory Manual of Developmental Biology and Veterinary Histology [19]. Tissues were microscopically examined, and the lesions categorized.

The leukogram results were analyzed by means of an ANOVA test using the Statistical ${ }^{\mathrm{TM}} 7.0$ program, making a comparison between groups and using a significance level of $\mathrm{p}=0.05$.

\section{Results}

All animals were clinically health at the beginning of the study, and the blood count determinations were within normal ranges for this breed [20].

All the rabbits inoculated with Dolphin Herpesvirus (groups E and F) died at $72 \mathrm{~h}$ post inoculation. Petechial hemorrhages were seen in several organs, being the most affected lungs, renal cortex, adrenal glands, liver, and gastrointestinal tract. All the observable lymph nodes and spleen were slightly enlarged. Histopathological lesions were mainly characterized by necrosis and hemorrhages; even though, a variable lymphoplasmacytic infiltrate was observed in most organs. Inclusion bodies were not seen in any case. The most apparent lymphoplasmacytic inflamation and petechial hemorrhages were observed in kidneys and brain. These results are very similar to those reported in canine puppies naturally infected with CHV-1 (active infection); in which lesion are illustrated by splenomegaly, pulmonary congestion, enlarged lymph nodes and petechial hemorrhages in lungs, liver, spleen, kidney, brain, and intestine; accompanied by multifocal coagulative necrosis [21] [22].

None of the rabbits inoculated with CHV-1 died, all were euthanized at $18^{\text {th }}$ day.

The animals to which dexamethasone was administered presented leukopenia, with lymphopenia $(p<0.05)$. The individuals in groups $\mathrm{A}, \mathrm{B}$ and $\mathrm{C}$, showed a 
clear decrease in total leukocyte count during treatment with dexamethasone. The decrease was maintained until day 18 (Figure 1). On the other hand, groups CII and D showed no statistically significant variations in the white blood cell count during the duration of the experiment. In animals in groups $\mathrm{E}$ and $\mathrm{F}$ it was not possible to count white blood cells due to death within 72 hours. Rabbits inoculated with CHV-1, revealed no histopathological lesion other than mild, diffuse, brain congestion (Figure 2).

Viral DNA was detected through nested PCR in multiple organs of individuals inoculated with Dolphin Herpesvirus (groups E and F) (Table 2 and Figure 3). Comparatively, in animals inoculated with $\mathrm{CHV}-1$, and treated with dexamethasone, spleen and lymph nodes were positive for PCR; likewise, in 4 of 8 animals, of group A, a mild positive reaction was observed in the central nervous system (Table 2). The remaining were negative for PCR in the various organs tested (Table 2 and Figure 3 ).

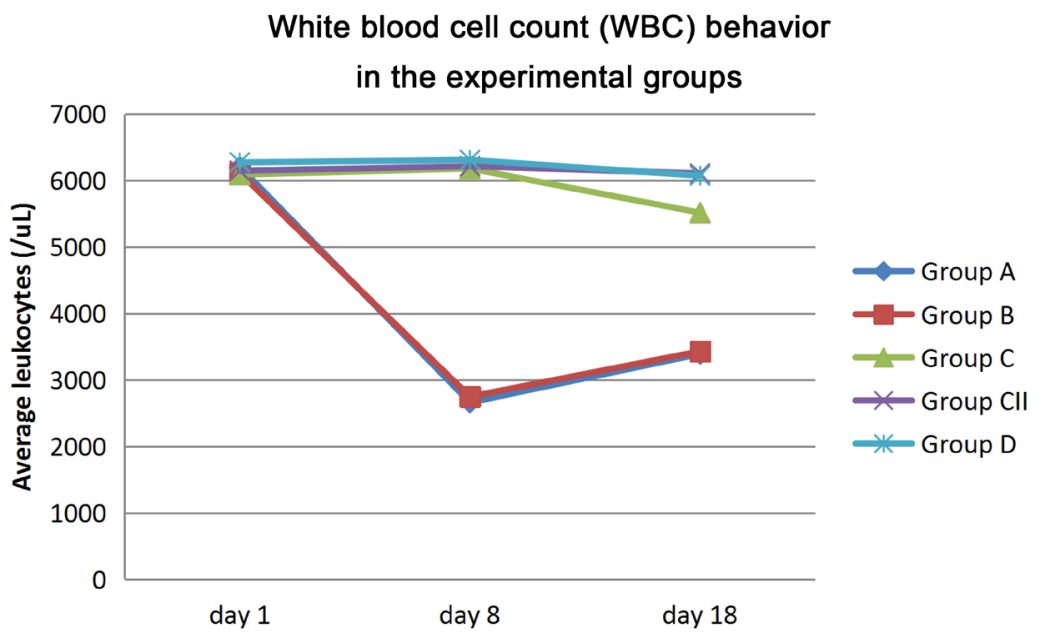

Figure 1. Effect on the total leukocyte count caused by the administration of dexamethasone in the distinct groups.

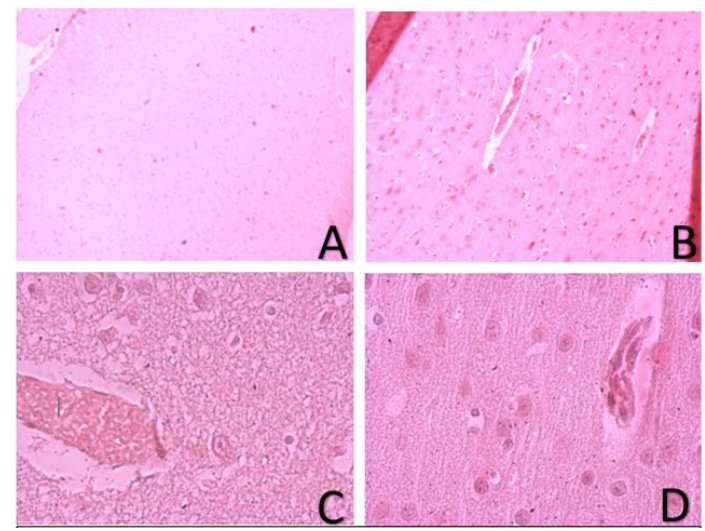

Figure 2. Histological sections of the brain, Hematoxilin-eosin stain, A. Rabbit C2 without histological alterations, 40×. B. Rabbit C5 without alterations 100×. C. Rabbit C8, mild diffuse congestion and perivascular edema, 400×. D. Rabbit C3 brain section without alterations, $400 \times$. 


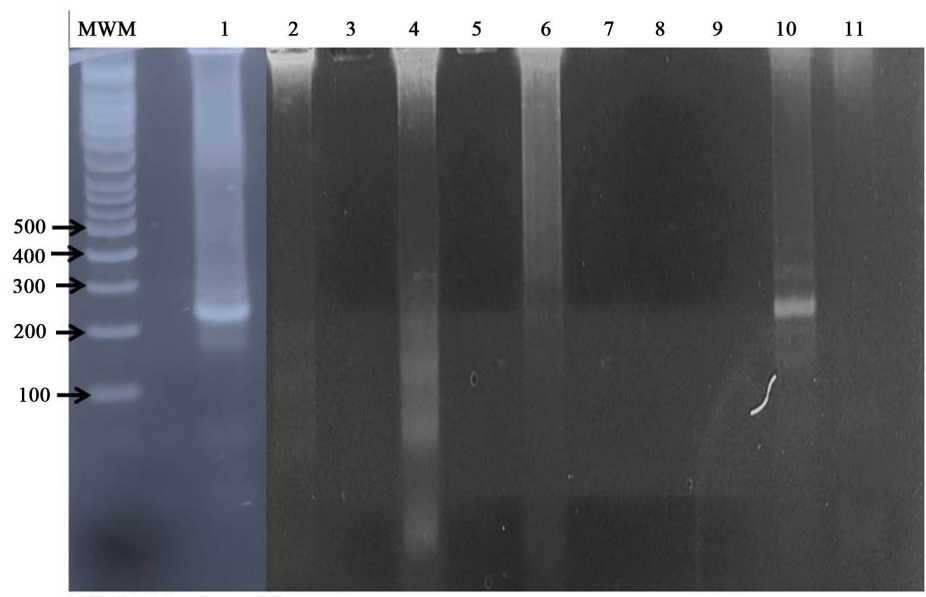

MWM.-Molecular weight marker,

Lane 1.-Rabbit F2 Kidney lane 6 rabbit A6, brain, lane 10.-Rabbit E1 liver

Lane 2.-Rabbit C4 Kidney, Lane 3.-A3 brain; Lane 4.-A3 kidney; Lane 5.-A3 Liver

Lane 7.-A2 liver; Lane 8.-A2 kidney; lane 9.-D1 Lymph nodes; Lane 11.-D1 Kidney

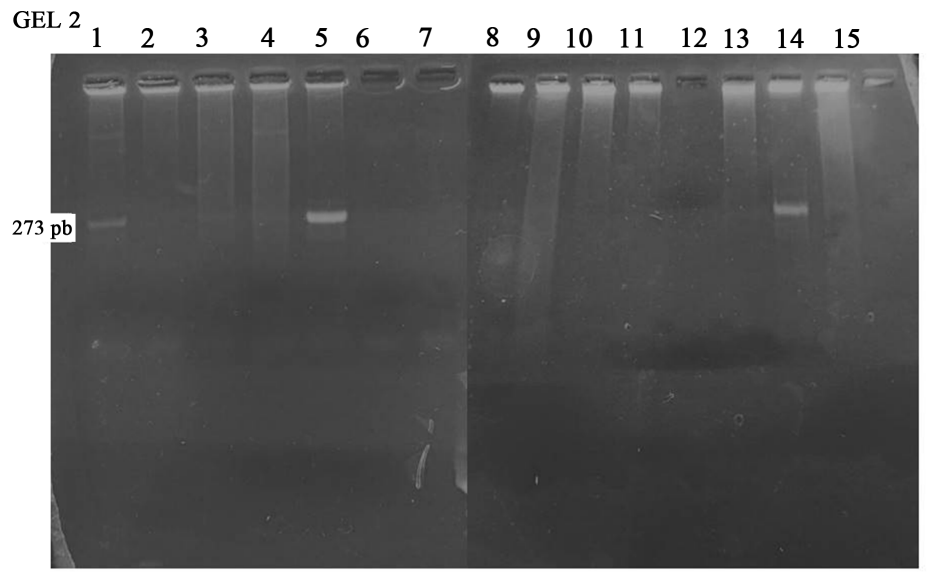

Lane 1.-Rabbit A1 Brain, Lane 5.-Rabbit A8 Iymph node, Lane 14.-Rabbit E2 kidney

L 2 (D4) Lymph nodes; L 3 (D4) Brain; L 4 (D4) Kidney; L 6 (CI3) Spleen; L 7 (CI3) Kidney;

L 8 (CII3) Brain; L 9 (CII3) Lymph nodes; L 9 (F1) Brain; L 9 (F1) Liver; L 10 (CI12) Lymph nodes;

L 11 (CII2) brain; L 12 (CII2) Kidney; L 13 (CI12) spleen; L 15 (Cl12) Liver.

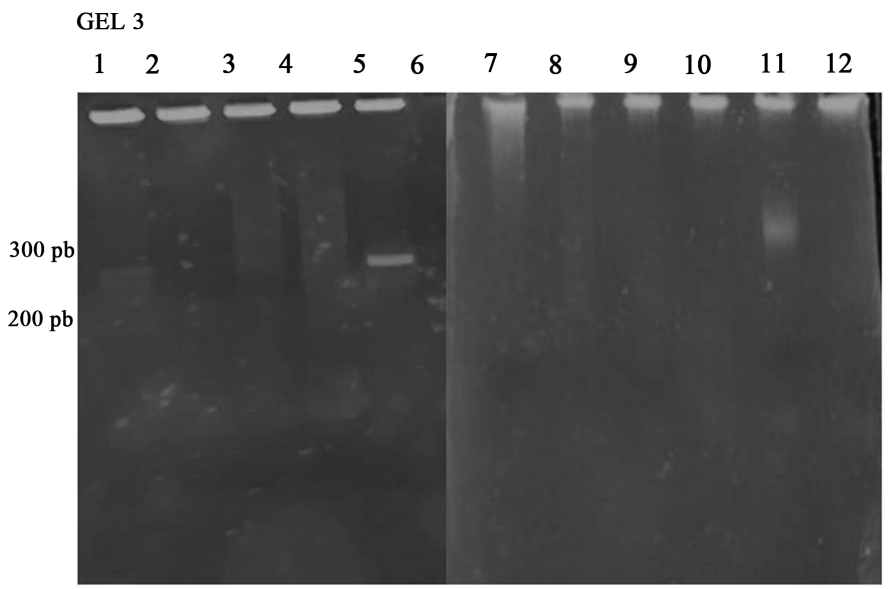

Lane 1 Rabbit F1 lymph nodes; Lane 5.-Rabbit F2 Liver, Lane 11.-Rabbit C3 spleen L2 (F1) Brain; L3 (F1) Liver; L4 (B1) brain; L6 (B1) Kidney; L7 (B1) spleen; L8 (B1) Liver L9 (B2) brain; L10 (B2) Kidney; L12 (B2) spleen

Figure 3. Agarose electrophoresis PCR products of some of the organs tested. GEL 1 (Lanes 1-11 and MWM), GEL 2 (Lanes 1 - 15) and GEL 3 (Lanes 1 - 12). 
Table 2. Results of the nested pcr for herpesvirus dna polymerase gene.

\begin{tabular}{|c|c|c|c|c|c|}
\hline \multirow{2}{*}{ IDENTIFICATION } & \multicolumn{5}{|c|}{ PCR Results (positive band) * } \\
\hline & LYMPH NODES & BRAIN & KIDNEY & SPLEEN & LIVER \\
\hline A1 & + & + & - & + & - \\
\hline A2 & + & + & - & + & - \\
\hline A3 & + & - & - & + & - \\
\hline A4 & + & - & - & - & - \\
\hline A5 & + & - & - & - & - \\
\hline A6 & + & + & - & + & - \\
\hline A7 & + & + & - & + & - \\
\hline A8 & + & - & - & + & - \\
\hline B1 & - & - & - & - & - \\
\hline B2 & - & - & - & - & - \\
\hline B3 & - & - & - & - & - \\
\hline B4 & - & - & - & - & - \\
\hline B5 & - & - & - & - & - \\
\hline B6 & - & - & - & - & - \\
\hline $\mathrm{C} 1$ & - & - & - & - & - \\
\hline $\mathrm{C} 2$ & - & + & - & + & - \\
\hline C3 & + & - & - & + & - \\
\hline $\mathrm{C} 4$ & + & + & - & + & - \\
\hline C5 & + & + & - & + & - \\
\hline C6 & + & + & - & + & - \\
\hline CII 1 & - & - & - & - & - \\
\hline CII 2 & - & - & - & - & - \\
\hline CII 3 & - & - & - & - & - \\
\hline CII 4 & - & - & - & - & - \\
\hline CII 5 & - & - & - & - & - \\
\hline CII 6 & - & - & - & - & - \\
\hline D1 & - & - & - & - & - \\
\hline D2 & - & - & - & - & - \\
\hline D3 & - & - & - & - & - \\
\hline D4 & - & - & - & - & - \\
\hline E1 & + & + & + & + & + \\
\hline E2 & + & + & + & + & + \\
\hline E3 & + & + & + & + & + \\
\hline $\mathrm{F} 1$ & + & - & + & + & - \\
\hline F2 & + & + & + & + & + \\
\hline F3 & + & + & + & + & + \\
\hline
\end{tabular}

After necropsy of rabbits, organs were removed, macerated, DNA was extracted, nested PCR was performed, and products were run by agarose gel electrophoresis, + indicates the presence of a molecular weight band $273-278 \mathrm{pb}$. 


\section{Discussion}

Dexamethasone phosphate was chosen due to its potency, that is, 5 times greater than prednisolone and of longer duration [23]. A severe leukopenia was induced after administration of dexamethasone in groups A and B, which could be associated with an immunosuppressed state. Some rabbits presented congestion in the brain and meninges, but histopathological analysis showed no vascular injury, therefore, we can suggest that the congestion could be due to the euthanasic method (cervical dislocation). During the performance of euthanasia, congestion and bleeding can be produced in the brain.

The results showed that positive controls generated an active infection with Dolphin Herpesvirus, while negative controls remained healthy throughout the experiment. Alpha-herpesviruses can produce more severe infections in non-natural host species than in their natural host, for example, isolates of the baboon alpha-herpesvirus inoculated in mouse produced lethal cross-species neurovirulence of baboon herpesvirus HVP-2. These results demonstrate that differences in a single viral gene can determine the severity of herpesvirus infection in a non-natural host species [24].

Rabbits inoculated with $\mathrm{CHV}-1$ and treated for 7 days with prednisolone, were PCR positive in the lymphoid organs, which may be associated with phagocytosed CHV-1 and carried to lymphoid organs, could represent latency within lymphocytes. This fact can be differentiated by in situ PCR tests, evaluating the cells that contain the viral DNA. However, the presence of viral DNA in the Central Nervous System after 18 days post infection further suggests a possible state of latency in rabbits, as demonstrated by [11], for Bovine Herpesvirus in rabbits. On the other hand, Pidone et al., in 1999 [10] in a scientific communication mention the effectiveness of Bovine Herpesvirus type 5 in replicating nervous signology in previously inoculated rabbits.

Okuda et al., in 1993, [25] used a dosage of $600 \mathrm{mg}$ of prednisone per dog per day, with 5 days of duration. The average weight of the dogs was $14 \mathrm{~kg}$; thus, the dose was approximately of $40 \mathrm{mg}$ of prednisone per $\mathrm{kg} / \mathrm{day}$. The maximum recommended dose for inducing immunosuppression is $4 \mathrm{mg} / \mathrm{kg} / \mathrm{day}$ [26]. Therefore, it can be determined that 10 times the maximum dose was used to achieve the immunosuppressive effect and demonstrating virus reactivation when presenting respiratory signology. On the other hand, Ledbetter et al. in 2009 [9], carried out a study in which dogs previously infected with canine herpesvirus were administered prednisolone at a rate of $3 \mathrm{mg} / \mathrm{kg} /$ day PO for 7 days. Viral reactivation was also achieved. Even though, only 3 times the maximum recommended dose was used to cause immunosuppression. It should be noted that the dogs in the Okuda experiment did not show signs of disease, although PCR amplification was able to demonstrate that the viral reactivation was successful. Likewise, evaluation of single dose or 3-day corticosteroid administration protocols in latently infected dogs resulted in mucosal $\mathrm{CHV}-1$ shedding without detectable recurrent disease [25] [27]. 
Although the therapeutic dose of dexamethasone in rabbits is 0.2 to 0.6 $\mathrm{mg} / \mathrm{kg} /$ day [28], in the present study, a dose of $4 \mathrm{mg} / \mathrm{rabbit} /$ day was used to reach a four-time higher dose, representing a slightly modification of what Ledbetter C. E., and Sung G. K., 2009 [9] employed in adult dogs. Likewise Mayer et al. in 2006 [11], submitted rabbits to dexamethasone treatment $(2.6 \mathrm{mg} / \mathrm{kg} / \mathrm{day}$, $\mathrm{im}$, for 5 days) to study the distribution of latent BHV-5 in the brain of rabbits. We used $4 \mathrm{mg} / \mathrm{kg}, 50 \%$ more and with a 7-day treatment duration.

Animals in group A treated before and after inoculation of CHV-1 apparently they were infected but in a latent form. However, treatment with dexamethasone after inoculation of CHV-1 did not induce viral reactivation, which is controversial to what was found by other authors with bovine herpesvirus in rabbits or demonstrated with CHV-1 in dogs experimentally infected. In dogs latently infected with CHV-1, generic immunosuppression appears inadequate to reactivate latent virus. Factors specific to corticosteroids or the immunomodulation associated with their mechanisms of action may be required to reactivate latent CHV-1 [1].

The 6 rabbits inoculated with HVC without prior or simultaneous treatment with dexamethasone were negative for the presence of the virus in the various organs analyzed at the end of the experiment, suggesting the participation of an immunosuppression event for HVC infection. It has been suggested that puppies of dogs are more susceptible due to the physiological immunosuppression they have at delivery and the first days after birth.

There are no more reports or studies on the infectivity of canine herpesvirus in other species or animal models. Herpesviruses are considered very species-specific or restricted range of hosts. Only few examples of infection between distinct species have been documented, but with milder lesions [8] [29], often explained by the absence of receptors for the virus. Our work suggests that it may be infection, but by natural resistance mechanisms, the virus can only cause a viral latency state.

This model in rabbits can be useful in studying the changes and lesions associated with latency in canine herpesvirus.

\section{Acknowledgements}

The work was partially funded by the project PAPIIT IT201218 "Development of a model in cell cultures to study the latency of canine Herpesvirus" of Universidad Nacional Autónoma de México, DGAPA.

\section{Supported}

This work was supported by the Project PAPIIT-UNAM IT201218 "Development of a model in cell cultures to study the latency of canine herpesvirus".

\section{Conflicts of Interest}

The authors declare no conflicts of interest regarding the publication of this paper. 


\section{References}

[1] Mundy, P., da Silva Erotides, C. and Ledbetter, E.C. (2012) Effects of Cyclophosphamide Myelosuppression in Adult Dogs with Latent Canine Herpesvirus-1 Infection Short Communication. Veterinary Microbiology, 159, 230-235. https://doi.org/10.1016/j.vetmic.2012.03.019

[2] Bascones, M.A. and Pousa, C.X. (2011) Herpesvirus. Avances en Odontoestomatología, 27, 11-24. https://doi.org/10.4321/S0213-12852011000100002

[3] Borches, K. and Field, H.J. (1999) Neuronal Latency in Human and Animal Herpesvirus Infections. Current Topics in Microbiology and Immunology, 253, 61-94. https://doi.org/10.1007/978-3-662-10356-2 4

[4] Kook, I. and Jones, C. (2016) The Serum and Glucocorticoid-Regulated Protein Kinase (SGK) Stimulate Bovine Herpesvirus 1 and Herpesvirus Simplex Virus 1 Productive Infection. Virus Research, 222, 106-112. https://doi.org/10.1016/j.virusres.2016.06.007

[5] Miyoshi, M. and Ishii, Y. (1999) Detection of Canine Herpesvirus DNA in Ganglionic Neurons and the Lymph Node Lymphocytes of Latently Infected Dogs. Journal of Veterinary Medical Science, 61, 375-379. https://doi.org/10.1292/jvms.61.375

[6] Ledbetter, E.C., Kice, N.C., Matusow, R.B., Dubovi, E.J. and Kim, S.G. (2010) The Effect of Topical Ocular Corticosteroid Administration in Dogs with Experimentally Induced Latent Canine Herpesvirus-1 Infection. Experimental Eye Research, 90, 711-717. https://doi.org/10.1016/j.exer.2010.03.001

[7] Burr, P.D. and Campbell, M.E. (1996) Detection of Canine Herpesvirus 1 in Wide Range of Tissues Using the Polymerase Chain Reaction. Veterinary Microbiology, 53, 227-237. https://doi.org/10.1016/S0378-1135(96)01227-8

[8] Valdes, S.M. (2009) Los modelos animales en la evaluación preclínica de antivirales contra los virus herpes simple. Revista de Salud Animal, 31, 86-92.

[9] Valera, R.A. (2011) Infeccion experimental por herpesvirus bovino tipo 1 en conejas gestantes. Revista Analecta Veterinaria, 31, 5-12.

[10] Pidone, C.L., Galosi, C.M. and Etcheverrigaray, M.E. (1999) Herpesvirus bovino 1 y 5. Analecta Veterinaria, 19, 40-50.

[11] Mayer, S.V., Vogel, F.S.F., Winkelmann, E.R., Arenhart, S., Weiblen, R. and Flores, E.F. (2006) Dexamethasone-Induced Reactivation of Bovine Herpesvirus Type 5 Latent Infection in Experimentally Infected Rabbits Results in a Broader Distribution of Latent Viral DNA in the Brain. Brazilian Journal of Medical and Biological Research, 39, 335-343. https://doi.org/10.1590/S0100-879X2006000300004

[12] Norma Oficial Mexicana NOM-062-ZOO-1999, Especificaciones técnicas para la producción, cuidado y uso de los animales de laboratorio.

[13] Quijano, B. (2006) El conejo como modelo animal para la reproducción de la infección corneal por Acanthamoeba polyphaga. Asociación Colombiana de Infectología, Vol. $10-12,80,81$.

[14] Valdivia Lara, E.G., et al. (2015) Isolation and Identification of Herpesvirus in the Bottlenose Dolphins (Tursiops truncatus) of Terminos Lagoon, Campeche México. Therya, 6, 495-504. https://doi.org/10.12933/therya-15-267

[15] NORMA Oficial Mexicana NOM-033-ZOO-1995, Diario oficial de la federación 07-16-96.

[16] Cardenti, M. and Rosa, B. (2006) Manual de Prácticas de Necropsia Patología General. FES Cuautitlán UNAM, 218-230.

[17] Valdivia Lara, E.G., Barrón Romero, B.L., Cobos Marín, L., Ángeles Solis, J.I., 
González Gallardo, S., Cuenca Verde, C., Montaraz Crespo, J.A. and Valdivia Anda, G. (2016) Pathology Isolation and Identification of Canine Herpesvirus (CHV-1) in Mexico. Open Journal of Pathology, 6, 111-121. https://doi.org/10.4236/ojpathology.2016.63014

[18] VanDevanter, D.R., Warrener, P., Bennett, L., Schultz, E.R., Coulter, S., Garber, R.L. and Rose, T.M. (1996) Detection and Analysis of Diverse Herpesviral Species by Consensus Primer PCR. Journal of Clinical Microbiology, 34, 1666-1671. https://doi.org/10.1128/JCM.34.7.1666-1671.1996

[19] Chávez, E.A. and Cornejo, C.M. (2011) Manual de laboratorio de biología del desarrollo e histología veterinaria. FES Cuautitlan UNAM, $130 \mathrm{p}$.

[20] Valdivia, A.G., Alba, H.F., Cortés, A.N., Montaraz, C.J.A. and Tortora, P.J.L. (2007) Desarrollo Morfohistológico del apéndice cecal del conejo. Revista Veterinaria México, 38, 319-330.

[21] Love, D.N. and Huxtable, C.R. (1976) Naturally-Occurring Neonatal Canine Herpesvirus Infection. The Veterinary Record, 99, 501-503. https://doi.org/10.1136/vr.99.25-26.501

[22] Carmichael, L.E., Squire, R.A. and Krook, L. (1965) Clinical and Pathologic Features of a Fatal Viral Disease of Newborn Pups. American Journal of Veterinary Research, 26, 803-814.

[23] Ramsey, I.K. (2013) Vademecum farmacologico de pequeños animales y exóticos. Septima edición, Ed. J.M. Sastre Vida, 582.

[24] Black, D., Ohsawa, K., Tyler, S., Maxwell, L. and Eberle, R. (2014) A Single Viral Gene Determines Lethal Cross-Species Neurovirulence of Baboon Herpesvirus HVP2. Virology, 452-453, 86-94. https://doi.org/10.1016/j.virol.2013.12.038

[25] Okuda, Y., Ishida, K., Hashimoto, A., Yamaguchi, T., Fukushi, H., Hirai, K. and Carmichael, L.E. (1993) Virus Reactivation in Bitches with a Medical History of Herpes Virus Infection. American Journal of Veterinary Research, 54, 551-554.

[26] Plumb, D.C. (2010) Manual de farmacología veterinaria. Sexta Edición, Intermedica, 1239.

[27] Okuda, Y., Hashimoto, A., Yamaguchi, T., Fukushi, H., Mori, S., Tani, M., Hirai, K. and Carmichael, L. (1993) Repeated Canine Herpesvirus (CHV) Reactivation in Dogs by an Immunosuppressive Drug. Cornell Veterinarian, 83, 291-302.

[28] Montesinos, A.B. and Morera, N. (2012) La clínica imprescindible en pequeños mamíferos para veterinarios generalistas. Avepa, 28.

[29] McGregor, A., Yeon Choi, K., Schachtele, S. and Lokensgard, J. (2013) Human Herpesviruses and Animal Models. In: Animal Models for the Study of Human Disease, Elsevier Inc., Amsterdam, Cap. 37, 906-924. https://doi.org/10.1016/B978-0-12-415894-8.00037-3 